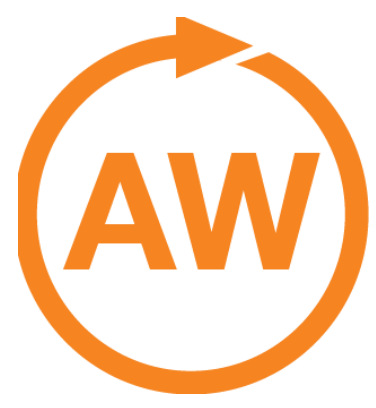

education review // reseñas educativas

a multi-lingual journal of book reviews

editors: gustavo e. fischman / melissa cast-brede / gene v glass

Supported by the Mary Lou Fulton Teachers College, Arizona State University

\section{It Takes Two \\ Henry L. Taylor}

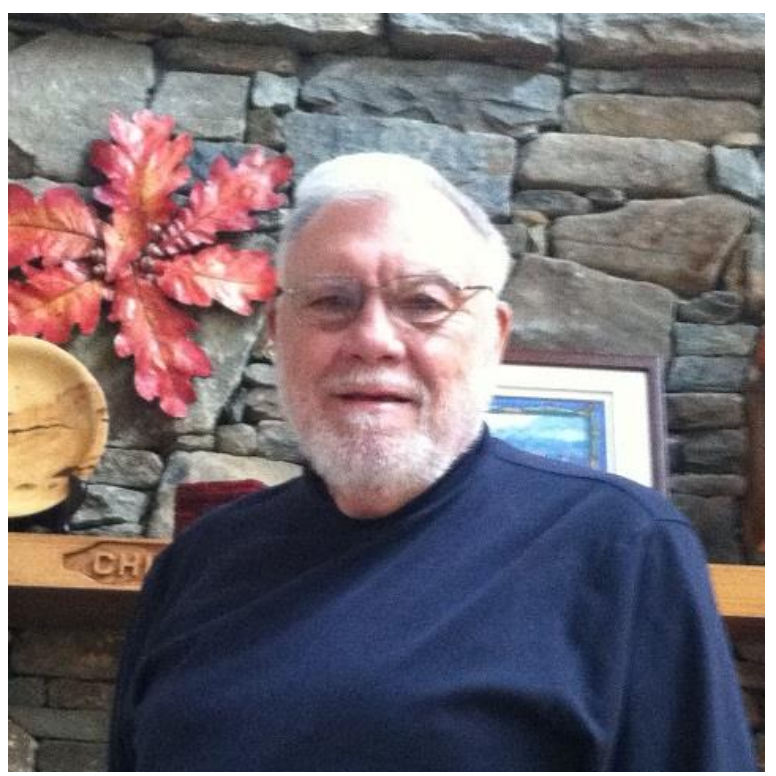

The most important principle l've learned during my career encompassing aviation and psychology is to take advantage of unexpected opportunities.

My interest in training and the use of training devices and simulators grew out of two careers and was a prominent feature in both. My careers involved 23 years in the United States Air Force and 21 years as Director of the Institute of Aviation at the University of Illinois, as well as six years as professor emeritus continuing my applied training research interests. Along the way, I should mention that I never have held a position in a university as a teacher and researcher but only as a dean-level administrator. What propelled me was the wisdom acquired during my Air Force career combined with a passion I developed for applied research in training and human factors.
This chapter is about how my professional life emerged from my roots in Tallassee, a small town located in central Alabama half way between Montgomery and Auburn, where I was born and grew up. It's about getting away from the local industries - cotton mills and farming - to attend college and unexpectedly join the Air Force. It's about the many places I've been and opportunities I've shared with wonderful and valued collaborators and colleagues. Most of all, it's about the events of my life and what I learned that shaped my career and may, in some small way, help with yours.

\section{Early Experience}

I attended the local high school, which had a graduating class of 104 students. Although neither of my parents graduated from high school, both of them believed that I should attend college and "get a good education". College was the way one got out of the cotton mill. I enrolled in a college preparatory course and was an A-B student. I became heavily involved in extracurricular activities including the concert and marching band, glee club, senior play (minor part), football, basketball and student government. Based on my interest in the latter, I was invited to attend the meeting of the Southern Association of Student Councils, which in 1951 met in Oklahoma City. I subsequently was elected to represent our school as president of the association. I believe that all these activities prepared me for leadership positions. I should also note that a broken nose playing football my sophomore year figured in a turning point later in my career.

In the fall of 1952, I enrolled in Auburn University. I had worked the 
previous summer installing industrial air conditioning in a textile mill. My meager savings would have to get me through freshman year since I knew that I could expect no contribution from my family. I was able to get a job waiting tables, and I worked for my meals through college. Influenced by an older cousin, I enrolled in the pharmacy program, which turned out to be a poor match, and I later transferred to Psychology in the College of Education. My poor performance during my first two years provided substantial motivation for my junior and senior years.

Auburn was a land grant university requiring all male students to enroll in the Basic Reserve Officer's Training Corp (ROTC) during their freshman and sophomore years. Auburn had programs in Army, Navy and Air Force. I chose the Air Force primarily because they didn't have to carry a gun during drills, despite my not being enthused about flying.

When it came time to apply for the advanced Air Force program, I couldn't pass the physical due to the broken nose from high school. After two quarters without a deferment and being concerned that I would be drafted, I had my nose repaired and entered the advanced program eligible to be trained as an aircraft navigator.

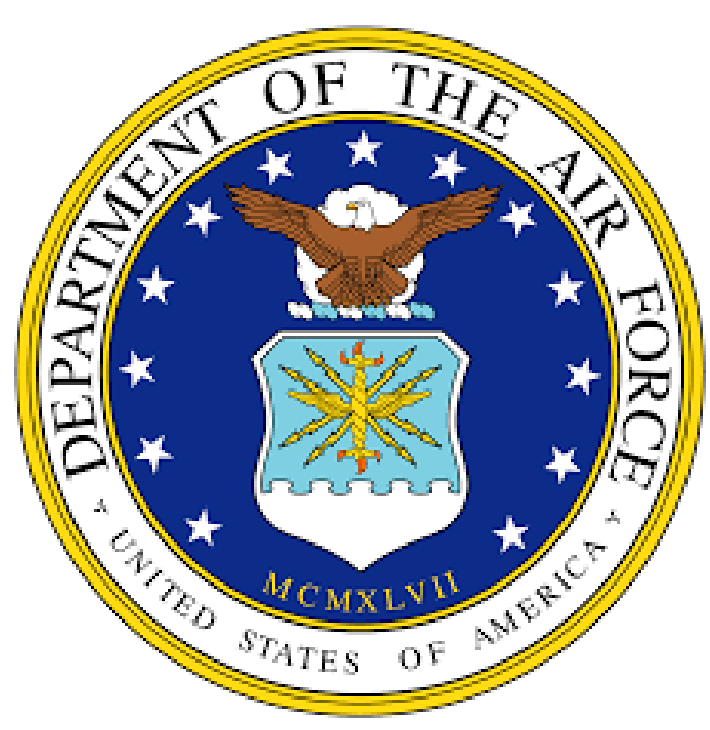

After graduation from Auburn in June 1956, I enrolled in a master's program in psychology and continued my ROTC. I married the love of my life, Mur Garrison, thanksgiving weekend of 1956. The support of my family - our three sons - and particularly the support of my wife has been a huge positive factor in my professional career.

I received a commission in the Air Force in March 1957, and petitioned for a six-month deferment to complete the master's degree. To my great surprise, I was designated military graduate eligible for a commission in the regular Air Force with a deferment until October 1957.

The Auburn Psychology faculty were all good teachers but none had a funded research program. I was interested in sensation and perception, and chose a thesis project concerning brightness enhancement in relation to the light-dark ratio of intermittent stimulation. The thesis was accepted in August 1957, and I entered the regular Air Force that October.

I was trained as an aircraft navigator and then as a radar observer (RO) on an aircraft with the mission to protect the northern border from hostile Russian bombers. After the RO's were joined by pilots, we trained to be combat ready together for the next three years. That first-hand experience with intensive flight training had meaningful effects on my career going forward.

I was upgraded to instructor RO. It was my duty to check out new pilots after their first two training flights in an airplane equipped with controls in the front for the student pilot and in the back for the instructor pilot. I was checking out a new pilot named Carl. Toward the end of the flight, when it was time to return to the airport, the weather ceiling had dropped and there was haze and fog in the area of the airport. We requested a straight in approach with radar control. The routine is for a pilot to follow the approach controller's commands until he can see the runway to land. The pilot has to be careful to maintain good speed control - not too slow nor too fast. On this approach, the airplane was not properly aligned for a safe approach and the pilot was trying to correct. The airplane was getting too slow 
and in danger of stalling. I yelled, "Take it around Carl!" and the airplane was shuddering as it started to gain normal flight speed. Carl performed flawlessly and we landed safely. This was training with real consequences!

In 1962, I was notified that I had been approved for a regular Air Force commission. I also discovered that I was eligible to apply for a $\mathrm{PhD}$ program in psychology at Air Force expense through the Air Force Institute of Technology (AFIT). One of the criteria was a master's degree. It's worth reflecting on the sequence of unexpected events that all were important to my being eligible: the broken nose, the failure to pass a flight physical, enrolling in graduate school to complete my advanced training, the deferment to complete the master's degree and finishing the thesis.

I applied to AFIT, was selected for a two-year $\mathrm{PhD}$ program, and was accepted by Florida State University (FSU). Most of my classmates had just completed their BS degrees while I had been out of school for five years. I experienced some significant anxiety during my first weeks of graduate school. I was fortunate in the first month to attend a research seminar with Dr. Virginia Zackert, an experimental psychologist with whom I worked on an Air Force research project at Auburn.

After the seminar, she took me aside and told me that I was smart but all the other graduate students were just as smart and that I was going to have to work to prove myself. She then laid out a rigorous study program (which included going to church on Sunday). She also said that I would establish in the first semester the quality of student I would be for my time at FSU. Carefully following her program resulted in an all-A first semester. $\mathrm{I}$ received one $\mathrm{B}$ during the summer semester and had all A's after that. Dr. Zackert's advice was important: early impressions do matter.

I routinely took a full course load with the Air Force paying for my tuition, fees, and books. In addition, I received my regular Captain's salary, housing allowance, and flight pay. So, I was able to be eligible for qualifying exams in the spring semester of my second year and passed all subject areas.

In January 1965, I petitioned the Air Force for an additional semester to finish my dissertation and take the comprehensive exams. I completed the dissertation, "Electrophysiological Studies of Dark Adaptation in the Noctuid Moth, Agrotis subterranea" and defended in May 1965. My departmental seminar presentation was two weeks before I was scheduled to leave. My career was progressing, but not yet focused on training research, only on my own training in the Air Force and in college.

\section{Transition to Training Research}

After receiving my Ph.D. from

FSU, I was assigned to be a behavioral scientist in the Psychological Research Branch, 6571 ${ }^{\text {st }}$ Aeromedical Research Laboratory, Holloman Air Force Base (AFB), NM (June 1965-December 1967). This is the lab that prepared and trained the two chimpanzees, Ham and Enos, for space flight prior to Alan Shepard's' and John Glen's historic flights. The lab's mission was to use subhuman primates to determine the behavioral effects of hazard environments with the goal to extrapolate to human behavior.

You've probably read that chimps are smart, and these were no exception. We were housing the chimps in a 30 -acre natural environment with a moat and an electrified wire above the moat. It was assumed the chimps wouldn't get their feet wet, and the wire was an additional deterrent. One chimp jumped into the mote, pushed the wire under water and scaled the fence to escape. It's a lesson about how to never underestimate research subjects and their creativity.

My work was in a new area of research investigating the behavioral effects of laser radiation and, in particular, its effects on response times. The 
practical concern was about the possible use of laser weapons and how they could disrupt pilot performance. The subject for the study was the rhesus monkey, Macaca Mulatta.

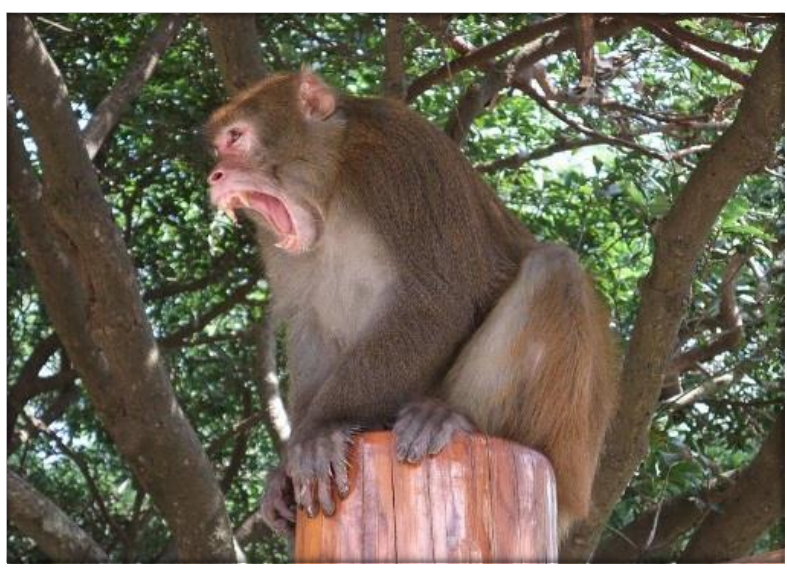

I developed a discriminate avoidance operant task and trained three rhesus monkeys to a stable baseline. Each was required to match a sample of three colors with a stimulus. Making an incorrect response or allowing time to lapse resulted in a mild electric shock. Those data provided a cumulative record of a response curve as baseline performance. The dependent variable was any delay in response following pulsed laser radiation. The data supported a significant but temporary disruption of responding. This research was the subject of two presentations: the Gordon Research Conference and the Northeast Electronics Research and Engineering Meeting (Taylor \& Ebbers, 1966).

The opportunity to meet distinguished researchers is an important part of career choice and development. One such opportunity occurred when Professor Holger Hyden, University of Göteborg, Sweden, approached the lab concerning a joint research project.

Previously, he had found in rats that the nuclear RNA was formed as part of the learning process. During the early part of training, the nuclear RNA had a DNA-like base ratio while the RNA formed when the animals had reached asymptote had a ribosomal base composition. He wanted to replicate his findings in rhesus monkeys. I was selected by the lab to conduct the training and learning studies.

Our findings failed to replicate the results from the rat studies. However, to prepare for the project, we were asked to visit Hyden's laboratories in Sweden. In addition, our lab commander, Dr. (Col) Kratochvil arranged for us to visit thirteen other research laboratories in Europe where, on behalf of the Air Force, he had had provided research funds for projects of interest to the US. Our visits included London Zoological Society, University College of London, University of Cambridge, Oxford University, L'Hôpital de la Salpêtrière, Max-Planck Institute of Physiology, University of Stockholm, and Karolinska Institutet. The visits were a unique and unexpected professional experience.

Other projects that began my transition to training research similarly concerned a combination of training and physiological psychology (e.g., Taylor, Smith, \& Hatfield, 1967; Taylor, Smith, Wall, \& Chaddock, 1968) which added to my knowledge and skills. My research career was engaged.

\section{Transition to Program Management}

I received a call in September 1967 from the Air Force officer in charge of assignments. He informed me that the Secretary of Defense had a policy that officers completing an AFIT graduate program would be assigned to Vietnam after two years in their first duty assignment. He indicated that I would be a navigator on a C130E cargo aircraft. I told him that I would be better qualified to be a GIB (guy in the back) of a 2-seater F4 aircraft due to my RO training and that I had never served as a navigator since basic navigator training. After some discussion, he said in a command tone, "Captain, I have a C130 navigator position to fill and you are it. You can choose your base." I chose the 345 Tactical Airlift Squadron, Ching Chang Kang, Taiwan. I then received three weeks of survival 
training and $7 \frac{1}{2}$ weeks of replacement training in the C $130 \mathrm{E}$ aircraft. I served in Vietnam from March 31, 1968, to June 1, 1969. I flew 157 combat missions and I had a total of 710 combat flying hours. During my tour I was upgraded to instructor navigator. It was another unexpected Air Force experience with applied training.

After I completed the combat tour, I expected to be reassigned to the Aeromedical Research Lab. Instead, my career as a program manager was to begin. I was one of three officers in the Air Force who was qualified to manage what was called human resources research and was selected for the job in 1969. I became an experimental psychologist and staff scientist at Andrews Air Force Base (AFB), MD to be program manager for the behavioral sciences. My responsibilities included providing support and oversight for personal research at a lab in Texas and training research at a lab in Ohio. I also managed training divisions newly established in Arizona and Colorado. These labs were co-located with the user to provide ideas for research and participants for tests. The typical problems of establishing a new organization, i.e., program development, funding and personnel, had to be addressed.

I was at a decided disadvantage since I didn't know the scientists involved in personnel and training research nor was I familiar with the personnel and training literature. Further, I did not know any of the important researchers in this area within the lab or outside it. To address my disadvantage, I set up an intensive travel schedule to visit all labs and meet with the principal investigators. I wanted to see the in-house lab space, review existing research programs, and meet lab personnel. I also had to review and understand the programs being done by contractors and what research objectives they addressed. I read everything in Air Force files and began to read the scientific literature.

Among the labs I visited was the Training Research Lab in Ohio. This was the lab of Gordon Eckstrand, the psychologist who started his 33-year career there in 1949 and became Director. I think that the most important project was the Advanced Simulator for Undergraduate Pilot Training (ASUPT). It became the primary research tool to determine ways to improve Undergraduate Pilot Training (UPT). The design consisted of two independent cockpits, which simulated the T-37B, the Air Force's primary jet training aircraft.

The cockpits were mounted on six degrees-of-freedom motion platforms to simulate the onset of kinesthetic cues.

These cues were sustained by a "G-seat," a device that mimics the higher gravity that a pilot would experience in real flight characteristic of a fast military fixed wing jet. Each simulator had a wrap-around visual display system consisting of seven video channels which displayed images generated digitally by a computer. The computer-generated images (CGI) were presented on a very wide field of view. The project pushed state-of-the-art

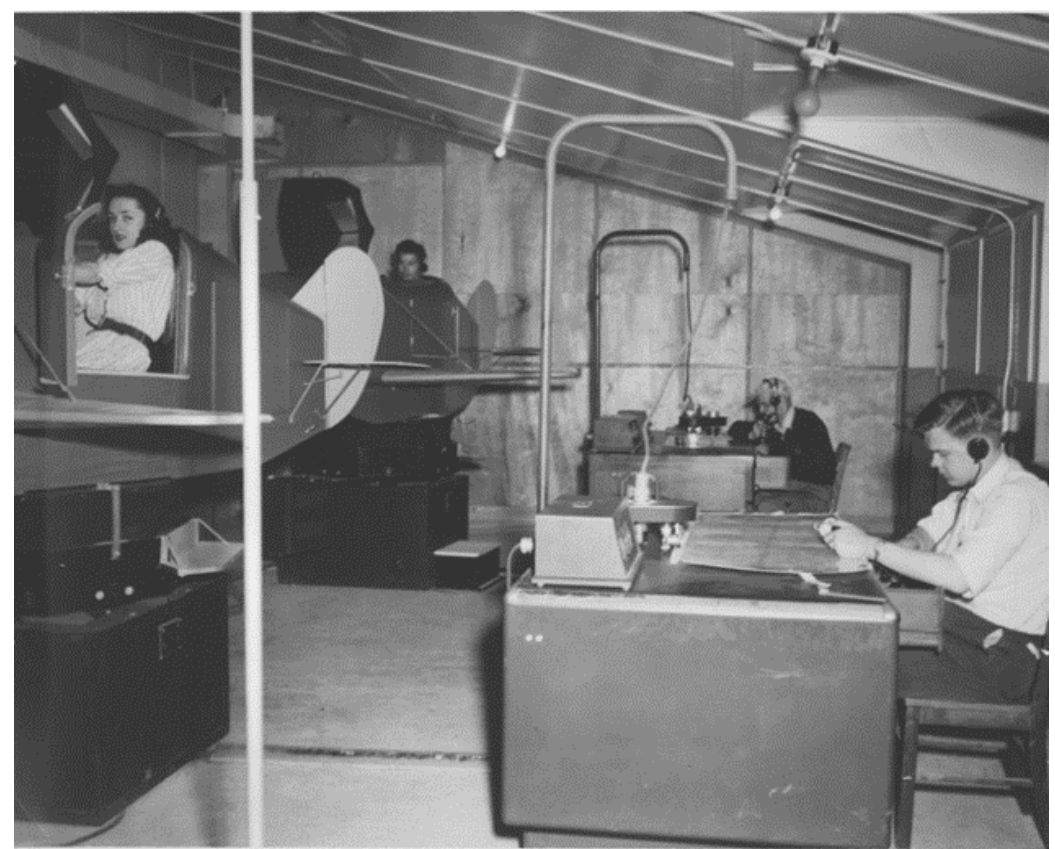


advancements in CGI and displays, simulator motion and gravity. The contracts to build the simulator went to Singer-Link and to General Electric and Farran Optical for the visual display. The ASUPT was installed for research use in Mesa, Arizona, in 1975 (Taylor \& Stokes, 1986).

Subsequent modifications to the ASUPT provided for the simulation of two tactical prominent fighter aircraft, the A-10 and the F-16. The simulator was renamed the Advanced Simulator for Pilot Training (ASPT). The cockpit configuration and the name change emphasized a change in research emphasis from undergraduate pilot training to advanced training including combat mission training.

A number of studies demonstrated that the ASPT provided a significant contribution to combat training. A-10 pilots flying the ASPT learned offensive and defensive combat maneuvers in a simulated hostile environment (Kellogg, Prather, \& Castore, 1980). A later study demonstrated that aircrew members trained in the ASPT to deliver air-tosurface weapons improved their initial weapon delivery performance in the A-10 aircraft (Gray, Chun, Warner, \& Edwards, 1981). In addition, Hughes, Brooks, Graham, Sheen, and Pickens (1982) found that prior training in the ASPT by experienced A-10 pilots significantly increased survivability in a simulated hostile threat.

A second project of note was the Advanced Instruction System (AIS). In May 1976, a 53-month, multimillion-dollar contract was awarded to McDonnell Douglas for developing the AIS to manage student progress and training resources (i.e., computer-managed instruction) rather than using the computer as a tutor (i.e., computer-assisted instruction). There were two major objectives: (a) develop a computer-based, multimedia system to administer and manage individualized technical training and (b) use AIS as a research test bed to determine the cost- effectiveness of training innovations. The original requirements of AIS were for three courses on precision measuring equipment, inventory management, weapons mechanics, and a computermanaged instruction system for 2,100 students per day. In 1979, the system configuration was expanded to manage 3,000 students and four courses per day. The evaluation of the AIS indicated that the savings in student training time was 40\% (Lintz, Parnell, \& Yasutake, 1979).

The management of Air Force research programs was a high visibility job with a lot of exposure to senior military officers and civilians. The ASPT and the AIS required a significant amount of my time to assure that they were funded. This included resolving conflicts with other projects.

In a notable example, senior Air Force staff were concerned that the ASPT and another advanced development project, the Simulator for Air to Air Combat (SAAC), were a duplication of effort even though the technology and the end users were different. The SAAC

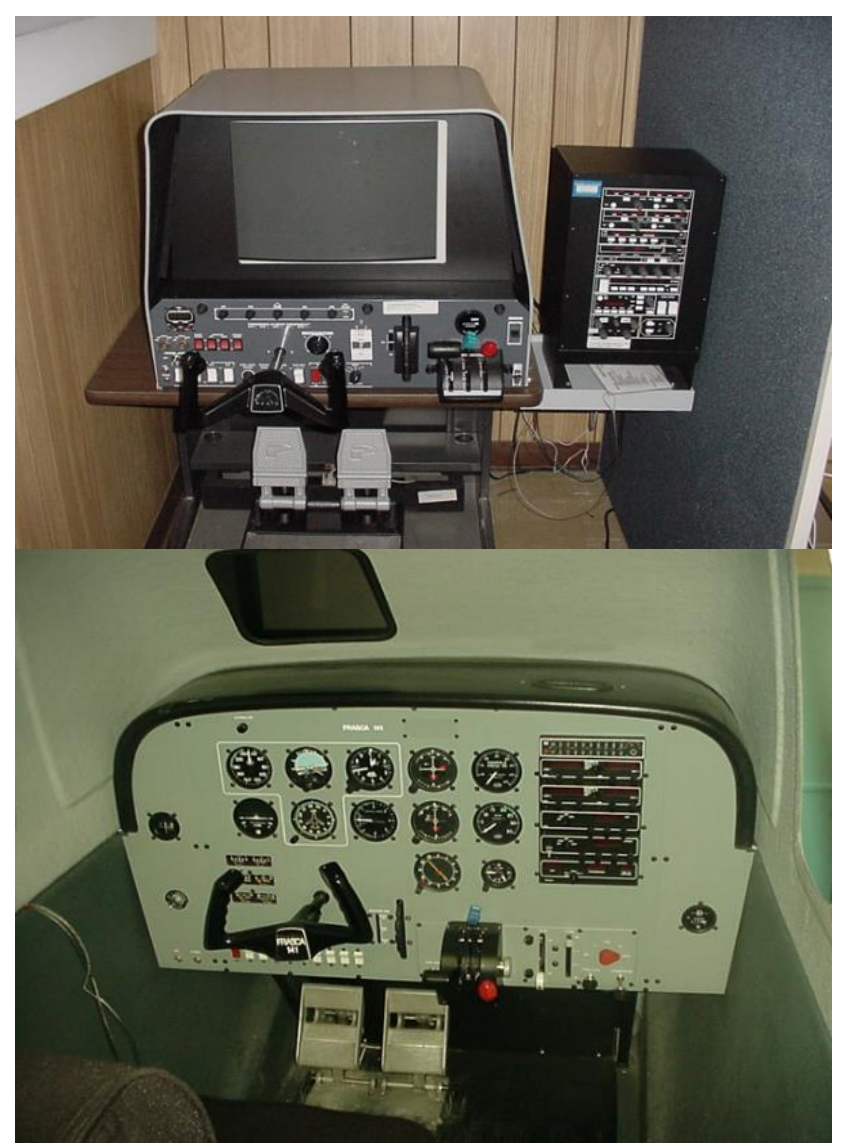


project manager and I were told to recommend which one would be eliminated and which funded. Instead, we recommended that neither should be eliminated. We provided a development schedule for both to be funded over a longer period. That finding initially encountered strong resistance which was resolved by delaying the SAAC for several years. I began to appreciate that research success often depends on good management as well as good ideas. My development of knowledge and skills in management had begun with a job in March 1972. That year, I was assigned as the military assistant for human resources in the office of the Assistant Secretary of Defense, The Pentagon. I believe that it was the most important position in my career field. My job was equivalent to the program manager job for the Air Force with one major difference. It encompassed all behavioral science research in the three military departments: the Army, the Navy (including the Marines) and the Air Force. We had a significant interface with the Congressional staff regarding programs and funding.

The new opportunity was to become knowledgeable with Army and Navy research programs and personnel, a significant increase in both the depth and breadth of my experience. It also meant that I was responsible to address any duplication of effort among the many programs including familiar ones in the Air Force.

The Arab oil embargo in 1973 and the resulting energy crisis gave a major boost to the use of simulator and training device procurement as well as to research and development in this area. In 1973, I was part of a study group to consider increased use of flight simulators for military training. The purpose was to prepare trade-off analyses to show if simulators could be a substitute for the high operating and maintenance costs of using aircraft for training. The study's recommendations resulted in a substantial increase of $\$ 164$ million to procure simulators for the fiscal year 1975 budget request. During this period, the Government's Office of Management and Budget established as a goal through the greater use of flight simulators for the military to reduce flying time by $25 \%$ by the early 1980s.

Subsequent recommendations to increase funding for simulators became the subject of a congressional hearing before the Subcommittee on Research and Development, Committee on Armed Forces. Senator Barry Goldwater, a fiveterm United States Senator from Arizona and the Republican Party's nominee for President in the 1964 election, presided. The hearing was to be friendly to support funding for flight simulators. Prior to the hearing, I had worked with Robert Q. Old, professional staff member of the Committee. We had exchanged questions that would support the growing budget. It was my task to prepare the remarks and the written testimony for my Pentagon boss and to also be the principal back-up. In his opening remarks, Senator Goldwater reviewed the budget requests for flight simulators, which had increased from $\$ 269$ million in fiscal year 1975 to $\$ 542$ million projected for fiscal year 1978 . He then listed the items that the Subcommittee was interested in hearing about: Is there a sufficient research base to support such a rapid increase in funding? Is the increase in research and development $(\mathrm{R} \& \mathrm{D})$ catching up on necessary research support? What is the relationship between $\mathrm{R} \& \mathrm{D}$ programs and ongoing and planned procurements? What research has been done on the motion and visual cues required to provide realistic simulation? What R\&D is being done on visual systems? What evidence have you found that learning transfer takes place? All obviously were important and probing questions of the kinds we must have in mind when doing training research.

Questions of that kind were the basis of a 1974 Defense Science Board Task 
Force $^{1}$ on Training Technology to evaluate the effectiveness of programs and management of R\&D on training technology. The purpose was to provide technical, management and operational guidance in reducing costs and increasing effectiveness of training for our military defense forces. The focus was to find ways to reduce the cost of such training and education estimated to be in excess of $\$ 7$ billion per year. The task force was a group of distinguished educators and scientists from academia and industry. I was honored to be selected as the Government's representative and Executive Secretary.

representatives who complied data to address the questions. The Task Force heard from numerous informed persons interested in training technology.

In each functional areas of training, the scope, costs and effectiveness of the training were examined. A key finding was that training methods which have been effective in the laboratory need to be tested and evaluated in the training schools and operational commands. Throughout the study the importance of incentives and disincentives arose. The Task Force found encouraging changes, which are taking place in military training such as how well the trainee can do the job. In each functional area the problem of 'institutional memory' was found.

Another major finding was that cost effectiveness was playing a minor role in Training Technology R\&D. Cost data are difficult to develop and effectiveness,

The Task Force concentrated on six applied areas of training and their rich opportunities for research. The areas were: Flight Training Technology; Weapons Systems Training Subsystems Development and Technology; Recruit or Basic Individual Training Technology; Individual Specialized Skill Training Technology; Crew/Group/ Team/Unit (CGTU) Specialized Skill Training Technology; Officer Acquisition Training and Professional Development Education. Prior to each monthly meeting, questions were developed by each chapter leader, which were revised and then submitted to the service particularly if one deals with readiness, is difficult to measure. It also recommended incorporating cost-benefit analyses of training procedures and equipment as a means of evaluating $R \& D$ programs and increasing the assignment of R\&D personnel, manpower economists, and cost analysts to major training establishments.

$$
\text { Crew/Group/Team/Unit (CGTU) }
$$
training deserves special mention because it is so unlike individual training. One novelty is the multiple ways of characterizing collectives - the result of deeply embedded traditions and terms used in the military services. There

${ }^{1}$ The Defense Science Board, established in 1956, appoints committees of civilian experts to advise the U.S. Department of Defense on scientific and technical matters. 
are flight crews, Army units, Seal teams, and so on. Aside from that, technically and financially, and unlike individual training, CGTU training is embedded in the operating forces. It is managed differently than individual training, a potential inefficiency, combined with very little R\&D about good practices.

Advances, at the time, in hardware technology, such as the laser, digital dataprocessing, and large-scale integration of digital circuits constituted potential for improving CGTU training. The Task Force recommended that CGTU test beds be established for all four military services and that instructional technology be incorporated into flight and other simulators to improve the effectiveness of the devices. This focus on multi-person training continues to have consequences for training research well beyond my career.

The CGTU recommendation and one other stand out for me as having the most impact on training technology (Defense Science Board Report of the Task Force on Training Technology 1976). That report established the importance of cost effective analyses for training technology programs. I initiated a program to develop such analyses, which had a significant influence on service $R \& D$ programs and continues to be a topic needing attention in 2017.

\section{Back to Academia - Sort of}

I knew I wanted to go into academia after I retired from the Air Force. I thought that I was qualified to serve as a Dean of Research at Auburn University. However, I knew already, after having lunch with the President of Auburn, that my lack of academic credentials - despite many publications - was against me. My career choices were guiding me perhaps more than I was guiding them.

In the fall of 1979, I was invited to apply for the Director of the Institute of Aviation, University of Illinois, as a deanlevel administrator. I knew about the outstanding research that the Aviation Research Laboratory (ARL) in the
Institute had performed when Stanley Roscoe was its head. Stan was notable in the field of aviation and training. He earned the first $\mathrm{PhD}$ in what is now known as engineering psychology from the University of Illinois, specializing in aviation experiments both in flight and in flight simulators. From 1952 to 1969, at Hughes Aircraft Company, he pioneered the application of flight and simulator experiments to the design of flight displays and controls and weapon-delivery systems. After that, he returned to the University of Illinois at Urbana-Champaign as a professor of psychology, aviation, and aeronautical and astronautical engineering. There, he founded ARL and established programs, funded mainly by the military and the Federal Aviation Administration, that supported an annual average of about 50 graduate students and staff. However, when I arrived, ARL no longer was a functioning lab.

My new administrative appointment at Illinois included academic responsibilities for the ARL, the Pilot Training Department, the Maintenance Training Department, and additional responsibilities as administrator as Director of Willard Airport, owned and operated by the University. I'll focus my discussion on research responsibilities in this description although running an airport presents its own unusual challenges.

My academic responsibilities soon increased. In August 1980, I was selected as a Professor with tenure. A year later, I received a zero-time appointment in Psychology. In addition, I was intent on pursuing my own interests in aviation research.

It was my intention to use the unique resources of the ARL - the training devices and simulators, the airplanes, the flight instructors and the flight students in research programs. We had about 350 flight students each year, so a substantial number were available for aviation human factors research and for simulator and training devices and training research. We 
were able to get grant and contract support to pursue these goals.

My first contract for research at the Institute was in 1981 to train aircraft maintenance personnel for Saudi Arabian Airlines. From 1981 to 1989 , I had a number of contracts examining the effects of various drugs on degradation of pilot performance. I was directing the research of two doctorial students. One was investigating the effects of organophosphate (poison) antidotes on pilot performance. Poisoning from these phosphates occurs from exposure to insecticides, medications, and nerve agents from drinking, breathing in the vapors, or skin exposure. Measures were made using the Frasca simulator (Dillinger, Taylor, Richardson, \& Wickens, 1985); Taylor, Dellinger, Schilling, \& Richardson, 1983; Dellinger \& Taylor, 1985; Dellinger \& Taylor, 1987). The other doctoral student was concerned with the effects of antiemetic (motion sickness) drugs on simulated pilot performance (Hyman, Collins, Taylor, Domino, \& Nagel, 1988). Pilot safety always is a high priority.

\section{My Principal Area of Research}

Shortly after I came to the Institute, I took flight lessons to insure that my research would be based on firsthand knowledge. I earned several credentials: Commercial Pilot Airplane Single Engine Land, Multi-engine Land, Instrument Airplane, Flight Instructor Airplane Single Engine Land, MultiEngine Land, and Instrument Airplane. I also, of course, could pilot a plane on trips as a side benefit of doing research on practical topics.

I started doing instrument training in the Professional Pilot program. I would schedule one student for a 6:00 a.m. flight time and still be in my office by 8:00 a.m.

The most interesting day was an early morning flight scheduled to fly to Decatur then to Springfield and return to Champaign. The weather was marginal with a low freezing level and a cloud ceiling of about 1000 feet. The flight was uneventful until we were climbing out of Decatur and picked up some freezing rain. Ice formed on the wings and the propeller. We continued to Springfield with full throttle but we were having trouble maintaining altitude and airspeed. I told the student to slowly descend to maintain airspeed. I asked him what our stall speed was and he gave me the book answer. I told him that we didn't know the stall speed due to the icing but 90 knots appeared to be safe since there was no evidence of stalling. I had him continue to fly the airplane but I was ready to take over if necessary. We were approaching the field from the downwind side and I declared an emergency and requested permission to land downwind. As we passed through the freezing level, the ice started to break up. We landed without incident and the FAA inspectors met us at the ramp.

By this time, my own research interests were clear: training research and the effectiveness of training devices and simulators. In 1985, I was invited to give the keynote address at the Symposium on the transfer of training to military systems, which was held at NATO headquarters, Brussels, Belgium. My paper was concerned with the training effectiveness 
of flight simulators as determined by transfer of training (Taylor, 1985). The research I worked on became the subject of several book chapters on flight simulators and training devices (Taylor \& Stokes, 1986); scene detail, field of view, and amounts of training on flight instruction (Taylor, Lintern, and Talleur, 1995); a civil view of aircrew training (Taylor and Emanuel, 2000); and the role of psychology in Air Force training and education (Mangelsdorff 2006). I've

\section{always believed that sharing our} research with others is equally and perhaps more important than doing it.

\section{Governance of Professional Organizations}

In the 1980s, I began to attend professional meetings as a way to share my current research and meet people with similar interests. One I attended regularly was the biannual International Symposium on Aviation Psychology. Other meetings of interest included Human Factors Society, Aerospace Medical Association, and the IEEE National Aerospace and Electronics Conference (NACON). The American Psychological Association (APA) also interested me, especially Applied Experimental and Engineering Psychology (Division 21) and Military Psychology (Division 19)

I became heavily involved in the governance of APA. For Division 21, I served as secretary, a member of the Executive Committee for many years, and President from 1988-1989. For Division 19, I was elected as a member at large for the Executive Committee, elected fellow in 1996, and was President in 2002-2003. I was elected to serve the APA Council of Representatives in 1995 and again from 2003-2007.

\section{A resolution concerning the} rights of gays and lesbians began during my tenure as Division 19 President. The executive committee requested that I give priority attention to repealing APA's ban on advertising for psychologists in journals by the

Department of Defense (DOD). At that time, the Defense Department would not (knowingly) allow gay and lesbian persons to enlist in the military. In 1993, Congress had passed a federal law allowing gay and lesbian persons to enter and serve in the military only if they did not engage in overt homosexual behavior and/or call attention to such contact - the "Don't Ask, Don't Tell" law. This was in conflict with APA's nondiscrimination policy. Division 19 and Division 44, the Division of Lesbian, Gay and Bisexual persons proposed an end to the advertising ban.

APA's President provided funding for an ad hoc committee to review the problem and make recommendations to the Board of Directors. The Board of Directors established the task force in October 2003. I was one of the three Division 19 appointees to the ad-hoc committee and there were three Division 44 members.

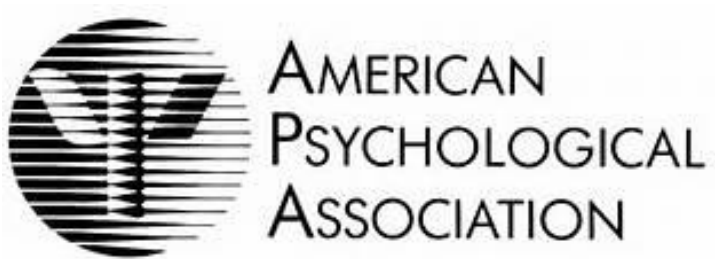

The committee met in January 2004 and was successful in drafting a new policy resolution on sexual orientation and military service. At its August 2004 meeting, the APA Council of

Representatives unanimously adopted the new policy, which reaffirmed existing APA policy on lesbian, gay and bisexual issues; updated, elaborated and strengthened the APA policy on sexual orientation and military service; and eliminated the APA's prohibition on advertisements from DOD.

This represented a remarkable resolution between two Divisions with a significant and important problem. For the next few years, it was not unusual for this outcome to be referred to as a model for solving problems.

In addition to professional organizations, I became involved with 
activities that occurred primarily outside the Institute of Aviation. One of these deserves special mention for its primary role in furthering applied aviation and training research. I was appointed to the Air Force Scientific Advisory Board, 19931997. The Board is composed of about 60 senior scientists who are nationally recognized in their technology field. I was on the Human Systems panel. The Board advises the Secretary of the Air Force and the Air Force Chief of Staff.

Each year, panels composed of Board members review the research and developments at laboratories in their area of expertise. Each year, all panels on the Board work on one overarching study problem defined in August. The panels work independently through the year on different parts of the study until all of them meet to integrate findings and recommendations. My most significant contribution was to the use of unattended aerial vehicles (drones).

Unattended aerial vehicles presented a vexing human factors and training problem: how to remotely pilot them. The topic had major implications due to the impact that drones and smart bombs have had on aerial warfare particularly regarding precision strike requirements. I served on the human systems panel and reviewed all research and development in human factors related to the problem. We visited Air Force Labs where research was being conducted. It was clear from our review of the work that the human factors problem had to be solved for aerial warfare using drones to be feasible. The problem was what information and skills were needed to control them.

On the first day of the annual meeting, the study director met with me and said, "Hank, I believe that the human factors problem is the long pole in the study." He had reached the same conclusion that we had. At the end of two weeks, the Board recommended that drones could be used effectively in aerial combat. This was a revolutionary concept in 1996. Today, precision drone strikes are commonplace. During our meetings that summer, we observed the first Predator remotely-piloted vehicle roll off the assembly line. An exciting era of aviation training had begun and continues in the $21^{\text {st }}$ century with requirements that span the military, shipping, and entertainment,

\section{My Mature Career} Each stage of a career has meaning that we often realize only after it has happened. That's true of the last 11 years of my professional career, which show how well focused I've become. As an administrator, it's about the events that led to the creation of Aviation Human Factors as a major at the Institute of Aviation at the University of Illinois. For research, it was about convincing the Federal Aviation Administration (FAA) of the importance of the flight training effectiveness of desktop computers.

A Research Capstone. My goal was to show empirically the viability and value of the flight training effectiveness of desktop computers. Today, I'd probably be studying the use of tablets or some other portable device as a trainer.

My specific objective was to provide a foundation, which justified the use of desktop computers for flight training guided by cockpit instruments instead of visual cues. A series of initiatives describes contributing steps toward success. I began by developing an experimental flight syllabus for testing PCbased aviation training devices followed by developing performance measures for evaluating personal-computer aviation training devices. The purpose was to show transfer of training effectiveness of personal computer-based aviation training devices.

The work resulted in documents and conclusions used by The FAA to make a rule about computer-based aviation training. FAA approved personal computers for 10 hours of instrument flight training toward an instrument rating 
in lieu of 10 hours in a training device or airplane. Anyone who would like to follow the sequence of publications can find them as follows: Emanuel, Taylor, Hulin, Lintern, Phillips, and Talleur, 1995; Phillips, Taylor, Lintern, Hulin, Emanuel, and Talleur, 1995; and Taylor, Lintern, Hulin, Talleur, Emanuel, and Phillips, 1999. It is very unusual for university research to have this kind of impact on national policy.

Administrative Success. Bringing academics and applied research together was my goal. I faced a number of challenges. The instructional staff of the Institute consisted of the faculty appointed in ARL and the academic professionals who taught in the pilot training department. It was necessary to develop incentives for each group. For the academic professional, we developed a promotion system and criteria that paralleled the tenure tract promotion system.

There were three levels of Aviation Education Specialists (AES): Assistant Aviation Specialist, Associate Aviation Specialist, and Professional Educational Specialist. One of the criteria was that each AES had a requirement to participate in the research program of the Institute. An AES initial appointment depended on a willingness to participate in research and the annual salary review included satisfying that requirement. The Provost agreed that the Institute could review the AES nominated for promotion and he would provide a salary increment equal to what faculty received.

The Institute supported Professional Pilot (PT) and Aircraft Maintenance Technology (AMT) as academic programs in addition to ARL for research. PT and AMT were non-degree programs with students receiving FAA certificates. In discussing the Institute's programs with the Provost, it was clear that he supported ARL and PT, but he felt that the AMT program was not related to any other campus program.
It was no surprise, with a significant reduction in state funding in 1992, that an Aviation Task Group was formed to examine the Institute of Aviation. The Task Group included three principal stakeholders in the Institute: Professor Donchin, head of Psychology. Joe Murtha of Civil Engineering, and myself. The group was charged to "consider how the human performance research, and possibly the professional pilot program, could be preserved if state funding for the institute was cut to zero". It also was asked to consider "what minimum budget from state funds would be required to preserve the human performance research and that part of the professional pilot program that is absolutely essential to it."

In answering the first question, the Task Group responded that a pilot training program is necessary (although a reduction in size is possible) to preserve human performance research in its current form. Therefore, if state funding were cut to zero, then other funding sources would need to be found such as increasing fees, charges to research grants etc. The Task Group found this was not fully possible.

In answering the second question, we estimated the state support needed for an appropriately-sized pilot training program matched to the needs of the research program. It would honor all tenure obligations and provide for modest infrastructure support for the Aviation Research Laboratory in order to maintain the human performance program. Administrative challenges keep coming up, particularly when the topics are groundbreaking as in the Institute's case.

One of the changes as a result of the Task Group's report concerned research appointments of the ARL faculty. They would be allowed to develop new aviation human factors courses consistent with their interest and the needs of the Institute. These additional courses provided the required course structure sufficient to propose an Aviation Human Factors BS degree. Having a degree 
program for the Institute was a longstanding goal. An additional requirement was for the degree to have academic program content consistent with campus standards. Finally, the course content needed to reflect the strengths of the Institute.

It had been a number of years since the state board of higher education had approved a new BS degree. The degree proposal combined two existing core programs-the Professional Pilot Program and the Aviation Human Factors Program. The latter used the core courses of the Engineering Psychology, and the additional courses developed by ARL faculty. There was no modification required to either core and this degree would represent a one-of- a-kind.

By 1995, all of the components of the degree proposal were in place and various review procedures were initiated with approval in 2000. At the University of Illinois commencement on May 13, 2001, I recommended the first two candidates for the Bachelor of Science in Aviation Human Factors. For the academic year of 20002001, we had 211 aviation majors and 141 of these were enrolled in the Aviation Human Factors Program. Sixty-three students were enrolled in the Professional Pilot Program. With the BS degree approved, the Pilot Training department's name was changed to the Professional Pilot Division and the Aviation Research Lab's name was changed to the Aviation Human Factors Division.

\section{Post-Retirement Career}

Staying well connected with colleagues and professionally active is the foundation of any research career. Students in graduate school today know the importance of communication very well with electronic devices of every size and shape making it routine. I took early advantage of being able to collaborate at a distance, which continued well into retirement.

I chose to retire in North Carolina, 600 miles from Illinois. Our research team continued with a weekly conference to discuss research and address problems just as when I was still at the Institute. I've written research proposals with three other co-principal investigators to compare the effectiveness of a personal computer aviation training device, a flight training device and an airplane in conducting instrument proficiency checks, and another to determine the transfer of training effectiveness of a flight training device. Our conferences and collaborations between 2001 and 2006 resulted in nine publications.

\section{Lessons Learned}

I discovered three major lessons from my experience with the Air Force, with college, and with research and management about human factors and training systems. They all relate to unexpected opportunities and molding them into a career as I went along.

\section{Taking advantage of opportunities.}

I learned that it was important to be able to take advantage of unexpected opportunities. Four were particularly important for me and useful examples.

The first arose on two different occasions. While I was in the Air Force, I was assigned to positions that I had not sought. The first was when I was at the Air Force Systems Command as the first program manager for the Human Resources Lab. This was a career changing job. I already have described how I had no knowledge of the technical area nor did I know any of the important researchers in the field. My success in the position eventually led to my assignment as the Personnel and Training program manager in the Pentagon.

The second opportunity was my decision to join the Departments of Psychology and the Department of Mechanical and Industrial Engineering in the Engineering Psychology program at the University of Illinois.

The third opportunity was learning the importance of being creative by using the total resources of the Institute of 
Aviation, - airplanes, simulators, flight instructors, students and the ARL faculty in the aviation research program at Illinois. No other collegiate aviation program has been able to duplicate our capability. No other university program has been able to establish a research program in aviation human factors. The BS degree program in Aviation Human Factors is unique since it has two core academic parts, the Professional Pilot core and the Aviation Human Factors core.

The fourth opportunity concerned the importance of developing a positive research culture and adapting with it. The Engineering Psychology faculty and staff had a seminar each week in which ongoing or proposed research was discussed. I have already discussed how I managed to make research appointments in ARL that required no teaching commitment. This changed in 1993 and the aviation human factors courses developed formed the core of the new BS degree program.

\section{Personal factors that stimulated my}

work. I believe the experience I had in operational flying as a radar observer and as a navigator in combat gave me an important perspective about research and development. Also my activities with professional organizations such as APA, Division 19, Military Psychology and Division 21, Applied Experimental and Engineering Psychology provided a significant richness in my professional career. It also gave me an opportunity to mentor junior faculty and researchers.

\section{Situational factors that stimulated}

my work. The Engineering Psychology program at Illinois enabled three departments, the Institute of Aviation, Department of Psychology, the Department of Mechanical and Industrial Engineering to join together, pool resources, share facilities, recruit high quality faculty, and negotiate university appointments that provided the best fit. This interdepartmental program was very successful as a special contribution to aviation research and graduate school and employment opportunities. Pardon me if I shamelessly advertise the benefits that you, the reader, could enjoy.

I've learned, and you should also, to cherish and nurture the very special relationships you develop from early in your career. For example, my dissertation advisor had a significant impact on me personally even though my research direction changed after grad school. I've already written at length about the important role of so many at the University of Illinois. My exposure to personnel in Defense management at The Pentagon added a major dimension to my career. I learned many lessons both there and from senior personnel at the Institutes for Defense Analyses (IDA) and at the Air Force research labs. I urge you always to be looking for those opportunities to grow and change.

\section{Some Final Thoughts}

You may wonder how my career experiences may influence yours and my advice about applied vs. academic research. There are many things in common between my career and one in academics. There is, however, one important difference. Applied research and its management addresses realworld problems with the satisfaction that goes with helping them to change. That isn't to detract but to emphasize the primary difference with academic research. My opportunities drew me into human factors and training where research and management both were essential components of "fixing things". I encourage the reader to think about that in his or her own career decisions.

In research, my major contribution still should seem relevant today if applied differently: the evaluation of the effectiveness of training devices and simulators to teach piloting skills. Research using the transfer of training paradigm is needed more than ever to show where tradeoffs make sense vs. hours flying an aircraft or unmanned vehicles. The time a 
pilot can save by doing such training is a significant savings of funds and expensive aircraft maintenance.

In management, my major contribution was about the use of cost effective analyses for training technology programs. The cost and effectiveness of simulators combined with compelling research data about their utility is a major boost to their use for training and as important today as when I did the work. The objective of the research is the same even as the training devices and the air platforms continue to change.

In summary, careers are made of many events often not under our control. Success is how we deal with them.

\section{References}

Dellinger, J. A., \& Taylor, H. L. (1985). Measuring the Effects of Neurotoxicants on Flight Simulator Performance. Aviation, Space, and Environmental Medicine, 56, 254-257.

Dellinger, J. A., \& Taylor, H. L. (1987). The Effects of Atropine Sulfate on Flight Simulator Performance and on Respiratory Heart Period Interactions. Aviation, Space, and Environmental Medicine, 58(4), 333-8.

Gray, T. H, Chun, E. K., Warner, H. D. \& Edwards, J. L. (1981). Advanced flight simulator Utilization in A-10 conversion and air-to-surface attack training. (Publication No. AFHRL-TR-80-20). Williams Air Force Base, AZ: Air Force Human Research Laboratory.

Hughes, R., Brooks, R., Graham, P., Sheen, R., \& Pickens, T. (1982). Tactical ground attack: On the transfer of training from flight simulator to operational red flag range exercise. In Proceedings of the $26^{\text {th }}$ Annual Meeting of the Human Factors Society (pp. 596-600). Seattle, WA: Human Factors Society.

Hyman, F. C., Collins, W. E., Taylor, H. L., Domino, E. F. \& Nagel, R. J. (1988). Instrument Flight Performance under the Influence of Certain Combinations of Antiemetic Drugs. Aviation, Space, and Environmental Medicine, 59(6), 533-539.

Kellogg, H. O., Prather, D. C., \& Castore. C. H. (1980). Simulated A-10 combat environment. SAE Technical Paper 801187. doi:10.4271/801187

Kimeldorf, D. J. \& Hunt, E. L. (1965). Ionizing Radiation: Neural Function and Behavior. New York: Academy Press.

Lendrum, L., Taylor, H. L., Talleur, D. A., \& Emanuel, T. W., Jr. (2003). IPC data logger (a flight data recorder): Operation manual change 2 (AHFD-03-8/FAA-03-2). Savoy, IL: University of Illinois, Aviation Human Factors Division.

Lintz, M. M., Pennell, R., \& Yasutake, J. Y. (1979). Integrated test of advanced instructional system (AIS) (Tech Rep No. TR-79-40). Lowry AFB, CO: Technical Training Division, Air Force Human Resources Laboratory.

Taylor, H. L. (2006). Air Force psychology in training and education. In A. D. Mangelsdorff, (Ed). Psychology in the service of national security (pp. 111-124). Washington, DC: American Psychological Association. doi: 10.1037/11470-008

Taylor, H. L., Dellinger, J. A., Schilling, R. F., \& Richardson, B. C. (1983). Pilot Performance Measurement Methodology for Determining the Effects of Alcohol and other Toxic Substances. In A. T. Pope \& L. A. Waugh (Eds.), Proceedings of Human Factors Society $27^{\text {th }}$ Annual Meeting, (pp. 334-338). Human Factors Society.

Taylor, H. L., \& Ebbers, R. W. (1966). Effect of Pulsed Laser Radiation on Discriminative Avoidance Behavior. NEREM Record, 162-163.

Taylor, H. L. \& Emanuel, T. W., Jr., (2000). A Civil Aviation View of Aircrew Training. In H. F. O’Neil Jr. \& D. H. Andrews (Eds.), Aircrew Training and Assessment, (pp. 17-36). Mahwah, NJ: Lawrence Erlbaum.

Taylor, H. L., Lintern, G., \& Talleur, D. (1995). Effects of Scene Detail, Field of View and Amount of Simulator Training on General Aviation Flight Instruction. In N. Johnson, R. 
Fuller, \& N. McDonald (Eds.), Aviation Psychology: Training and Selection, (Volume 2, pp. 234-239). Aldershot, Hants, England: Avebury Aviation.

Taylor, H. L., Smith, J. C., \& Hatfield, C. A. (1967) Immediate detection of X-rays in the Rhesus monkey. 6571st, Aeromedical Research Laboratory, Holloman Air Force Base, New Mexico, Technical Report Number ARL -TR -67-20.

Taylor, H. L., Smith, J. C., Wall, A. H., \& Chaddock, B. (1968). Role of Olfactory system in the detection of X-rays by the Rhesus Monkey. Physiological Behavior, 3(6), 929-933.

Taylor, H. L., \& Stokes, A. F. (1986). Flight Simulators and Training Devices. In J. Zeidner (Ed.) Human Productivity Enhancement: Training and Human Factors Systems Design (Volume 1, pp. 81-129). New York: Praeger. 


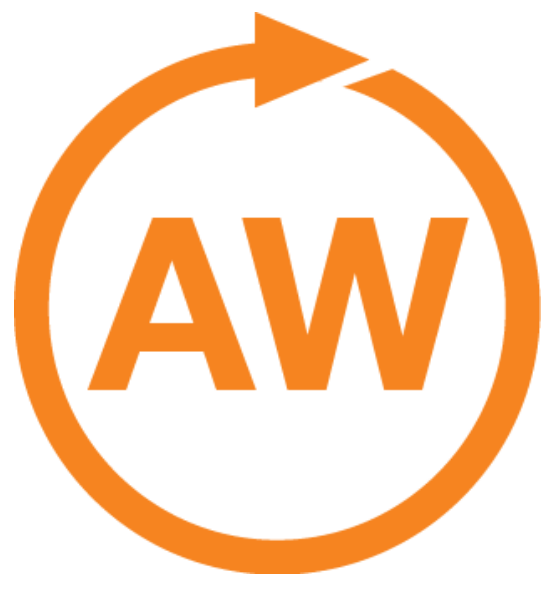

About Acquired Wisdom

This collection began with an invitation to one of the editors, Sigmund Tobias, from Norman Shapiro a former colleague at the City College of New York (CCNY). Shapiro invited retired CCNY faculty members to prepare manuscripts describing what they learned during their College careers that could be of value to new appointees and former colleagues. It seemed to us that a project describing the experiences of internationally known and distinguished researchers in Educational Psychology and Educational Research would be of benefit to many colleagues, especially younger ones entering those disciplines. We decided to include senior scholars in the fields of adult learning and training because, although often neglected by educational researchers, their work is quite relevant to our fields and graduate students could find productive and gainful positions in that area.
Junior faculty and grad students in Educational Psychology, Educational Research, and related disciplines, could learn much from the experiences of senior researchers. Doctoral students are exposed to courses or seminars about history of the discipline as well as the field's overarching purposes and its important contributors. .

A second audience for this project include the practitioners and researchers in disciplines represented by the chapter authors. This audience could learn from the experiences of eminent researchers-how their experiences shaped their work, and what they see as their major contributionsand readers might relate their own work to that of the scholars. Invitations to potential authors were accompanied by Tobias' chapter in this series for illustrative purposes. Authors were advised that they were free to organize their chapters as they saw fit, provided that their manuscripts contained these elements: 1 ) their perceived major contributions to the discipline, 2) major lessons learned during their careers, 3) their opinions about the personal and 4) situational factors (institutions and other affiliations, colleagues, advisors, and advisees) that stimulated their significant work.

We hope that the contributions of distinguished researchers receive the wide readership they deserve and serves as a resource to the future practitioners and researchers in these fields. 


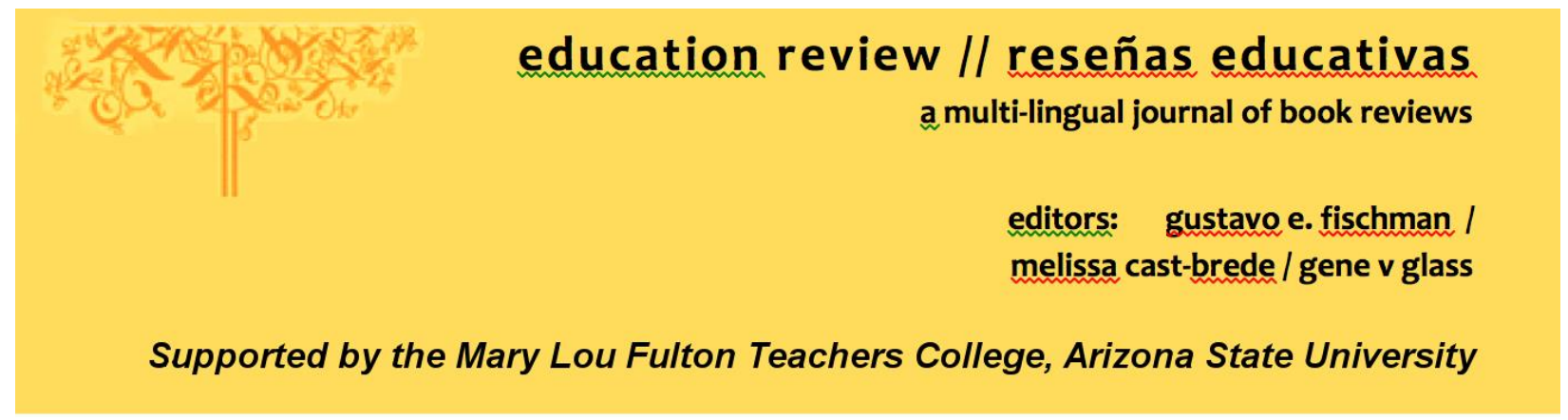

$\begin{array}{ccc} & \text { Acquired Wisdom is } & \\ \text { Edited by } & \\ \text { Sigmund Tobias } & \text { J. D. Fletcher } & \text { David C. Berliner } \\ \text { University at Albany } & \text { Institute for Defense Analyses } & \text { Arizona StateUniversity } \\ \text { State University of New York } & \text { Alexandria VA } & \text { Tempe AZ }\end{array}$

\title{
Advisory Board Members
}

Gustavo Fischman, Arizona State University

Arthur C. Graesser III, Memphis State University

Teresa 1. McCarty, University of California Los Angeles

Kevin Welner, Colorado State University

\begin{abstract}
Education Review/Reseñas Educativas/Resenhas Educativas is supported by the edXchange initiative's Scholarly Communications Group at the Mary Lou Fulton Teachers College, Arizona State University. Copyright is retained by the first or sole author, who grants right of first publication to the Education Review. Readers are free to copy, display, and distribute this article, as long as the work is attributed to the author(s) and Education Review, it is distributed for non-commercial purposes only, and no alteration or transformation is made in the work. More details of this Creative Commons license are available at http://creativecommons.org/licenses/by-nc-sa/3.0/. All other uses must be approved by the author(s) or Education Review. Education Review is published by the Scholarly Communications Group of the Mary Lou Fulton Teachers College, Arizona State University.

Please contribute reviews at http://www.edrev.info/contribute.html.

Connect with Education Review on Facebook (https://www.facebook.com/pages/EducationReview/178358222192644) and on Twitter@EducReview
\end{abstract}

